\title{
POPULAR RADICALISM IN NINETEENTH-CENTURY BRITAIN
}




\section{Social History in Perspective}

General Editor: Jeremy Black

Social History in Perspective is a series of in-depth studies of the many topics in social, cultural and religious history.

\section{PUBLISHED}

John Belchem Popular Radicalism in Nineteenth-Century Britain

Sue Bruley Women in Britain Since 1900

Anthony Brundage The English Poor Laws, 1700-1930

Simon Dentith Society and Cultural Forms in Nineteenth-Century England

Joyce M. Ellis The Georgian Town, 1680-1840

Peter Fleming Family and Household in Medieval England

Kathryn Gleadle British Women in the Nineteenth Century

Harry Goulbourne Race Relations in Britain since 1945

Anne Hardy Health and Medicine in Britain since 1860

Tim Hitchcock English Sexualities, 1700-1800

Sybil M. Jack Towns in Tudor and Stuart Britain

Helen M. Jewell Education in Early Modern England

Alan Kidd State, Society and the Poor in Nineteenth-Century England

Arthur J. Mclvor A History of Work in Britain, 1880-1950

Hugh McLeod Religion and Society in England, 1850-1914

Donald M. MacRaild Irish Migrants in Modern Britain, 1750-1922

Donald M. MacRaild and David E. Martin Labour in Britain, 1830-1914

Christopher Marsh Popular Religion in the Sixteenth Century

Michael A. Mullett Catholics in Britain and Ireland, 1558-1829

Richard Rex The Lollards

George Robb British Culture and the First World War

R.Malcolm Smuts Culture and Power in England, 1585-1685

John Spurr English Puritanism, 1603-1689

W.B. Stephens Education in Britain, 1750-1914

Heather Swanson Medieval British Towns

David Taylor Crime, Policing and Punishment in England, 1750-1914

N.L. Tranter British Population in the Twentieth Century

lan D. Whyte Migration and Society in Britain, 1550-1830

Ian D. Whyte Scotland's Society and Economy in Transition, c. 1500-c.1760

Andy Wood Riot, Rebellion and Popular Politics in Early Modern England

Please note that a sister series, British History in Perspective, is available, covering key topics in British political history.

\section{Social History in Perspective Series Standing Order \\ ISBN 978-0-333-71694-6 hardcover \\ ISBN 978-0-333-69336-0 paperback \\ (outside North America only)}

You can receive future titles in this series as they are published by placing a standing order. Please contact your bookseller or, in case of difficulty, write to us at the address below with your name and address, the title of the series and the ISBN quoted above.

Customer Services Department, Palgrave Ltd

Houndmills, Basingstoke, Hampshire RG21 6XS, England 


\title{
POPULAR RADICALISM IN NinETEENTH-GENTURY BRITAIN
}

\author{
JOHN BELCHEM
}




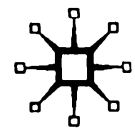

(1) John Belchem 1996

All rights reserved. No reproduction, copy or transmission of this publication may be made without written permission.

No paragraph of this publication may be reproduced, copied or transmitted save with written permission or in accordance with the provisions of the Copyright, Designs and Patents Act 1988, or under the terms of any licence permitting limited copying issued by the Copyright Licensing Agency, 90 Tottenham Court Road, London W1T 4LP.

Any person who does any unauthorised act in relation to this publication may be liable to criminal prosecution and civil claims for damages.

The author has asserted his right to be identified as the author of this work in accordance with the Copyright, Designs and Patents Act 1988.

Published by

PALGRAVE

Houndmills, Basingstoke, Hampshire RG21 6XS and

175 Fifth Avenue, New York, N. Y. 10010

Companies and representatives throughout the world

PALGRAVE is the new global academic imprint of

St. Martin's Press LLC Scholarly and Reference Division and

Palgrave Publishers Ltd (formerly Macmillan Press Ltd).

Outside North America

ISBN 978-0-333-56575-9

ISBN 978-1-349-24390-7 (eBook)

DOI 10.1007/978-1-349-24390-7

Inside North America

ISBN 978-0-312-15799-9 hardcover

ISBN 978-0-312-15806-4 paperback

This book is printed on paper suitable for recycling and made from fully managed and sustained forest sources.

A catalogue record for this book is available from the British Library.

Cataloging-in-Publication Data is available from the Library of Congress.

Transferred to digital printing 2002 


\section{Contents}

Acknowledgements

Introduction

1 The Eighteenth-Century Context: Civic Humanism, Commercial Liberalism and the Crowd

2 Radicalism, Revolution and War, 1790-1815

3 The Radical Mass Platform, 1815-20

4 Ideology, Public Opinion and Reform, 1820-35 51

5 Radicalism and Class, 1835-50

6 Radicalism, Liberalism and Reformism, 1850-75 102

7 Gladstone, Lib-Labism and New Liberalism

8 Labour's Turning-point?

9 Liberals, Labour and the Progressive Alliance 166

Conclusion: The First World War and After 184

Notes 


\section{ACKNOWLEDGEMENTS}

As much has been compressed in this brief study of radicalism in the 'long' nineteenth century, I must apologize to those scholars whose work I have misrepresented, overlooked or acknowledged inadequately. In the notes and the Guide to Further Reading I endeavour to clear some of my vast burden of intellectual debt. An old friend, Richard Price, and a new colleague, Jon Lawrence, have put me straight on a number of key issues, helping me to retain some semblance of balance and historical sanity, the 'linguistic turn' notwithstanding. Mary-Rose, my partner in radicalism, has done much to improve the quality of the argument.

Liverpool

J. B. 